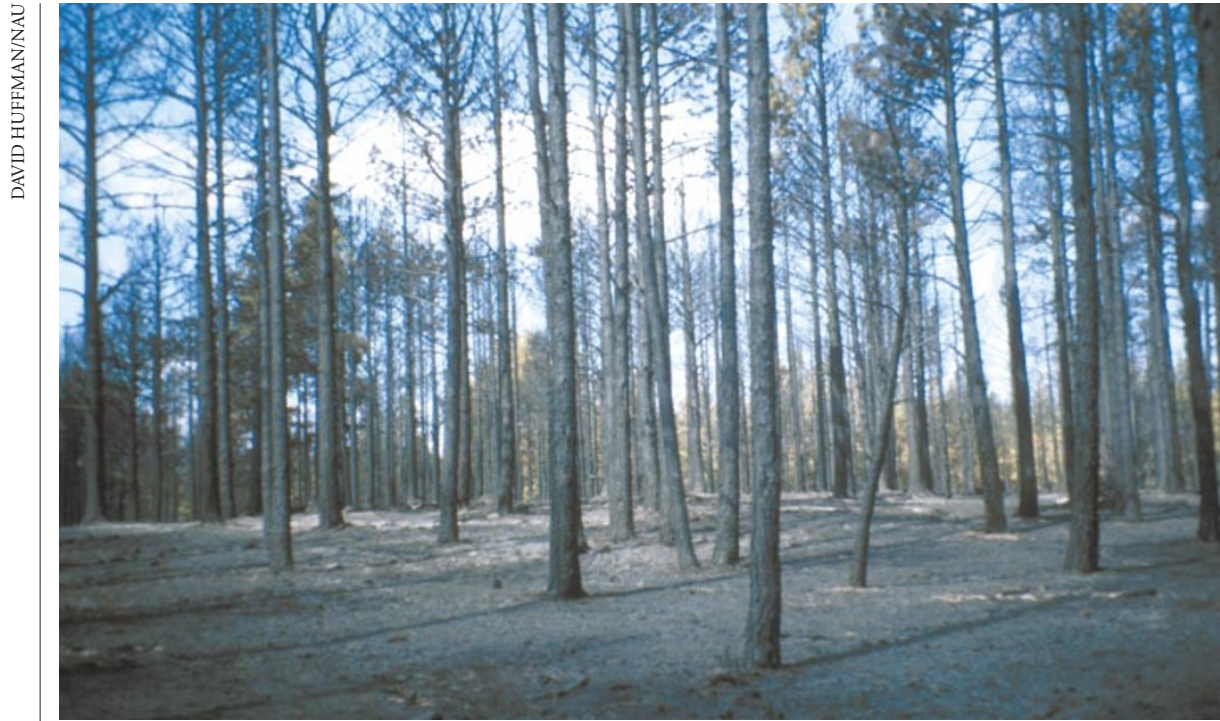

From trees to ash: this 'Woolsey' plot in Arizona, established in 1909, was among those destroyed.

\title{
US forest fires send ecology experiments up in smoke
}

\section{Paul Smaglik}

Fires that have laid waste to more than 2.4 million hectares of US forest this summer represent a double dose of ecological irony.

Not only have the fires destroyed historic research plots whose increasing concentration of trees over the past 90 years foretold this summer's disaster, but they have also consumed some newly established plots designed to investigate how to prevent such massive fires from flaring up again.

Although ecologists have not yet conducted a full survey of the damage, and the fire season is not yet over, blazes have already damaged or destroyed a third of the so-called Woolsey plots, which are among the oldest research plots in the country.

The plots, named after ecologist T. S. Woolsey, who led US forest-service workers in the early 1900s in counting, measuring and mapping each tree on the 50 plots, ranged from about 2 to 6 hectares in size.

They were surveyed every five years until the 1930s, when they were abandoned. Ecologists rediscovered them in the 1990s, but by then only about 15 remained, many of the others being lost to development.

The plots give ecologists a detailed history of the forest and its changing composition. They also document how the concentration of trees increased when the forest service decided to prevent fires in forests, rather than allow periodic ground fires to remove underbrush and dead trees.

The first time the foresters surveyed the plots there were 30 to 60 trees per hectare. That had risen to 2,000 in the 1990s. But higher concentrations of trees result in more intense fires that can consume even large trees completely, rather than the more desirable ground fires that leave them intact.

At least five of the remaining 15 Woolsey plots were badly damaged this summer. Two in Arizona's Fort Valley Experimental Forest, the oldest US forest-service research station, sustained heavy damage. One portion was "completely consumed", says David Huffman, a researcher at Northern Arizona University, Flagstaff, who inspected the area after the fires were brought under control.

Plots near Los Alamos and Las Vegas, New Mexico, are also likely to have been at least partly destroyed, although scientists have yet to assess the most remote regions.

The damage hits hard because few plots have detailed records stretching back 100 years. "We've lost a long-term historical record," says Margaret Moore, professor of forestry at Northern Arizona University.

Fires have also damaged experimental plots in Florida and New Mexico that are part of a larger study of the best methods to restore forests to the conditions documented when the Woolsey plots were established.

The project involves surveying three to four blocks of land at 11 sites around the country. Each block will feature four treatments: control, manual thinning, controlled burning, and thinning and burning. The aim of the project is to find the best ecological approach to reducing the threat of large fires.

In a sense, the project has courted its losses, as the plots are placed in the kinds of forest most threatened by fires. "We are risking losing our experiments to the problems we are trying to measure," says Jim McIver, the project's director.

http://www.for.nau.edu/ecorest/woolsey.htm
Electricity debt could mean lights out for Russian virus institute

Carl Levitin, Moscow \& Alison Abbott

The plug will literally be pulled on the D. I. Ivanovsky Institute of Virology in Moscow next week if the institute cannot pay its 800,000 roubles (US\$30,000) debt to its electricity provider, Mosenergo.

The institute's directors claim that much of its unique collection of viruses will be lost within hours of the electricity shut-down, as its supply of liquid nitrogen will not stretch to saving all strains. If this happens, another Russian scientific treasure will have fallen victim to the country's economic difficulties.

The institute's only income is from the Russian Academy of Medical Sciences. And, according to the institute's deputy director Petr Deryabin, it has no hope of raising the money by the 12 September deadline.

Mosenergo has already extended the original deadline by two weeks in acknowledgement of "the uniqueness of the institute". The debt has been accumulating since the beginning of last year.

Government departments have refused to help out, and the institute's international grants can only be used for designated research work, not for paying energy bills. "No one will be able to do any work without electricity, and the institute will have to close," says Deryabin. Moreover, he adds, it will be difficult to maintain safety conditions for containing the viruses.

The virus collection - more than 6,000 strains from 18 families — has been gathered over the past 60 years from around the former Soviet Union and through gifts and exchanges from virologists abroad. "It is an important collection historically and geographically," says Steve Elie, head of pathobiology at the chemical and

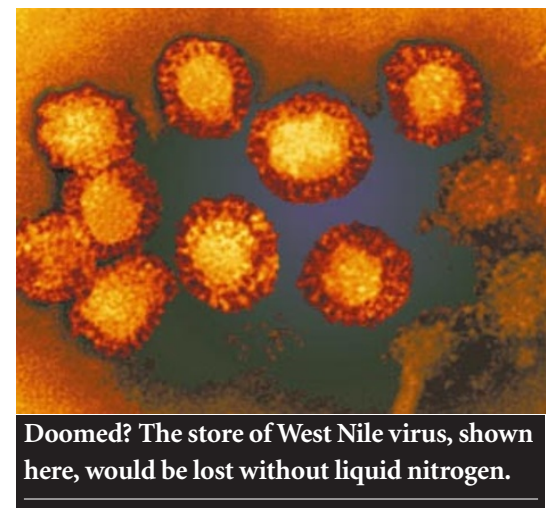


biological defence laboratories of Britain's Ministry of Defence.

Brian Mahy at the US Centers for Disease Control and Prevention says the threat is "extraordinary" considering the institute's value. The Ivanovsky Institute holds important collections of arthropod-borne viruses, he says, some of which have been collected from remote parts of the former Soviet Union and will be impossible to replace.

Particularly important, he says, is the institute's collection of the mosquitoborne West Nile virus. West Nile disease broke out in Russia a couple of years ago and reached the United States for the first time last year, causing five deaths in New York. The institute also has the world's best collection of tick-borne encephalitis viruses, says Mahy.

Despite facing the same difficulties as all Russian public research institutes, the institute has remained active. For example, it is a reference centre for monitoring influenza and other viral diseases for the World Health Organization.

The institute's director Dmitry Lvov, says that the collection "is one of Russia's real treasures and the country is going to lose it. It is a real tragedy." Lvov has asked various government departments for help. But he says the only response was from the Russian sanitary office, which sent a letter of protest to Mosenergo.

\section{Researchers practise martian living in the Canadian Arctic}

\section{Steve Nadis}

To prepare for life on Mars, a group of US researchers is exploring the next best thing - Devon Island, a barren, windswept outpost high in the Canadian Arctic.

Last month, investigators used a simulated martian habitat as a base for exploring the region. The aim is "to learn how to operate on Mars”, explains Robert Zubrin, president of the Mars Society, a private organization funding the project.

So far, $\$ 300,000$ has been spent, and additional money has been raised to support operations up to the end of next year. A fiveyear, $\$ 1$ million research programme is planned to complement a NASA programme begun on Devon Island four years ago.

Things got off to a shaky start in July, when one of five payloads dropped onto the island by parachute crashed to the ground, destroying floor panels for the habitat, a crane and a trailer.

The team recovered by bringing plywood from the nearest town and using pulleys and winches instead of a crane. "When we get to Mars, we'll have to be prepared to improvise," says Zubrin. "Ultimately, human ingenuity rather than technology will carry us through.”

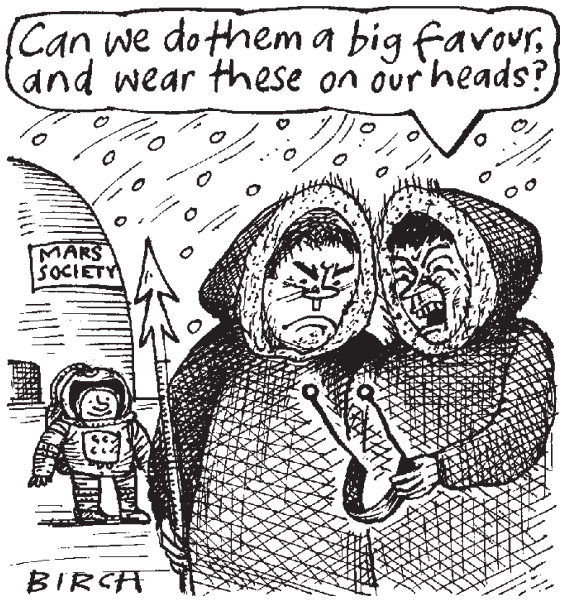

The six-person habitat, a 7.2-metre-high cylinder with a domed roof, was finished in late July, two weeks behind schedule, allowing for a shortened occupancy period of less than a week. Next summer, researchers will spend two months at the base.

The crew, which included NASA scientists, simulated operations on Mars, spending 20 minutes in an airlock and wearing spacesuits. They used all-terrain vehicles and communicated daily with 'mission control' centres in Houston and Denver.

\section{Californian centre will test medical uses of cannabis}

\section{Rex Dalton, San Diego}

Marijuana is about to come under close scientific scrutiny in California. The Center for Medicinal Cannabis Research is being set up by the University of California to study the drug's efficacy and safety.

Announced last week, the centre will study the effects of cannabis on a number of diseases, including AIDS, muscle spasticity and nausea caused by cancer treatment. Some biochemistry might also be funded.

California's state assembly has provided US\$3 million for the first year of research, and plans to fund two more years at $\$ 3$ million each. Any research institution in California can apply for funds from the centre, which will be a venture between the university's San Diego and San Francisco campuses. Research proposals will be reviewed by a national panel of experts and approved by the National Institute on Drug Abuse, which will also supply the cannabis.

The plan is to start enrolling patients and conducting studies in January, according to Igor Grant, a physician at the University of

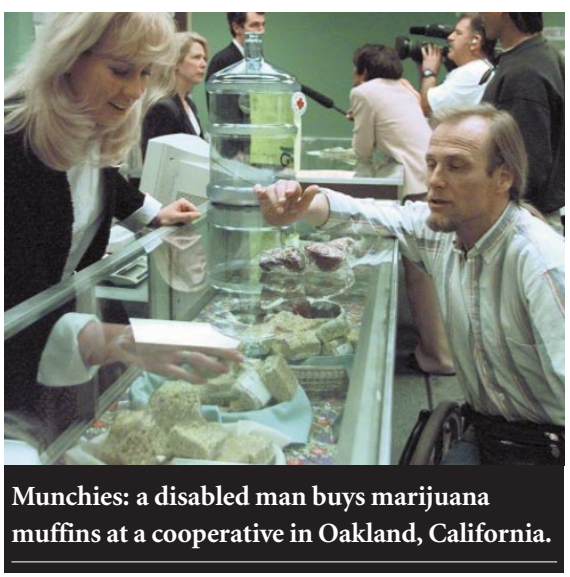

California at San Diego and co-director of the centre. He says that clinical trials and studies should provide reliable evidence on whether any medicinal benefits can be derived from smoking marijuana or ingesting marinol, a synthetic version of marijuana's most active ingredient, THC (delta-9-tetrahydrocannabinol).

Although there are surveys and retrospective studies on the purported positive medicinal effects of cannabis, there are few prospective, blinded studies on the drug. US federal authorities have balked at funding such studies, concerned that they might encourage abuse of marijuana.

But in recent years, several prestigious scientific groups have called for a comprehensive cannabis study. Earlier this year, the National Academy of Sciences' National Research Council issued a report recommending research on cannabis.

California has voted to make cannabis legal for medicinal use, and 'cannabis clubs' provide marijuana for various purported health needs. This has prompted legal battles between state authorities and federal prosecutors, who fear that medicinal use will be used as a cover for criminal activity.

As these disputes went on, California state Senator John Vasconcellos, a Democrat from Santa Clara, successfully pushed the bill to fund the cannabis research centre through the state assembly.

i http://ucsdnews.ucsd.edu 